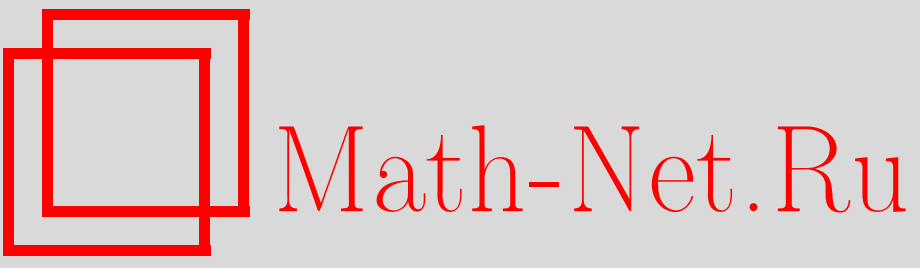

M. K. Khasanov, S. R. Kil'dibaeva, Mathematical model of gas hydrate formation of sulfur dioxide by injecting liquid sulfur dioxide into a layer saturated with methane and water, Vestn. Udmurtsk. Univ. Mat. Mekh. Komp. Nauki, 2020, Volume 30, Issue 1, 125-133

DOI: https://doi.org/10.35634/vm200109

Use of the all-Russian mathematical portal Math-Net.Ru implies that you have read and agreed to these terms of use

http://www . mathnet.ru/eng/agreement

Download details:

IP : 34.229 .108 .108

April 26, 2023, 15:53:49 
MSC2010: 93A30

\author{
(C) M. K. Khasanov, S. R. Kil'dibaeva
}

\title{
MATHEMATICAL MODEL OF GAS HYDRATE FORMATION OF SULFUR DIOXIDE BY INJECTING LIQUID SULFUR DIOXIDE INTO A LAYER SATURATED WITH METHANE AND WATER
}

This paper presents the results of a theoretical study for the gas hydrate formation of sulfur dioxide by injecting liquid sulfur dioxide into a layer saturated with water and methane. Self-similar solutions of a straight-line parallel problem are constructed. The dependences of the temperature and the coordinates of the formation front of sulfur dioxide gas hydrate on the layer permeability are explored. It is established that, as the layer permeability increases, the temperature of the phase transition increases on the surface. As a result, at sufficiently large values of layer permeability, the temperature at the hydrate formation border may exceed the equilibrium decomposition temperature of sulfur dioxide gas hydrate, which will correspond to the appearance of an intermediate region saturated with a mixture of water, sulfur dioxide and its gas hydrate in a state of thermodynamic equilibrium. It is established that at sufficiently high values of injection pressure and permeability, the gas hydrate formation of sulfur dioxide will occur in the extended region.

Keywords: mathematical model, self-similar solution, porous area, filtration, gas hydrates, sulfur dioxide.

DOI: $10.35634 / \mathrm{vm} 200109$

\section{Introduction}

One of the ways to reduce the emission of sulfur dioxide into the atmosphere is the utilization of sulfur dioxide produced by industrial facilities in gas fields depleted [1-3]. However, there is a risk of leakage of sulfur dioxide in fluid form to the surface during its long-term underground storage. This risk can be minimized by converting sulfur dioxide into a gas hydrate state, which, in comparison with its free state, allows storing the same amount of gas at much lower pressures [4-7]. The mathematical models of hydrate formation in a porous medium are formulated, in particular, in [8-10]. The mathematical model of sulfur dioxide gas hydrate formation by injection of liquid sulfur dioxide into a porous medium saturated with water and methane is explored. It explores the conditions under which an extended area of the hydrate formation of sulfur dioxide occurs.

\section{§1. Problem statement}

The thermobaric existence conditions of the formation of sulfur dioxide hydrate are represented in the phase diagram (Fig. 1) [4]. In this diagram, the curve 1 corresponds to the threephase equilibrium between gaseous sulfur dioxide, its gas hydrate and water, the curve 2 shows the two-phase equilibrium between gaseous and liquid sulfur dioxide, and the curve 3 represents the equilibrium between liquid sulfur dioxide, its gas hydrate and water. $\mathrm{SO}_{2}$ gas hydrate exists above the curve 1 and to the left of the curve 3, i. e., at sufficiently high pressures and low temperatures. At the upper quadrupole point $Q_{2}\left(T_{Q}=285,1 \mathrm{~K}\right.$ and $\left.p_{Q}=0,233 \mathrm{MPa}\right)$ gaseous and liquid sulfur dioxide, as well as its gas hydrate and water are in equilibrium. Let's assume that the semi-infinite horizontal layer in its initial state is saturated with water with the initial saturation $S_{w 0}$ and water. We assume that the layer initial temperature $T_{0}$ is lower than the temperature $T_{Q}$ 
corresponding to the quadrupole point, and the initial pressure $p_{0}$ corresponds to the thermodynamic conditions of the sulfur dioxide existence in its liquid state and its gas hydrate (i. e., above the curve 2 in Fig. 1). Therefore, in the case under consideration the initial state of the system corresponds to the thermobaric conditions of $\mathrm{SO}_{2}$ gas hydrate existence. Let's assume that liquid sulfur dioxide is injected through the border $(x=0)$, the pressure $p_{e}$ and the temperature $T_{e}$ of which correspond to the conditions of sulfur dioxide gas hydrate existence.

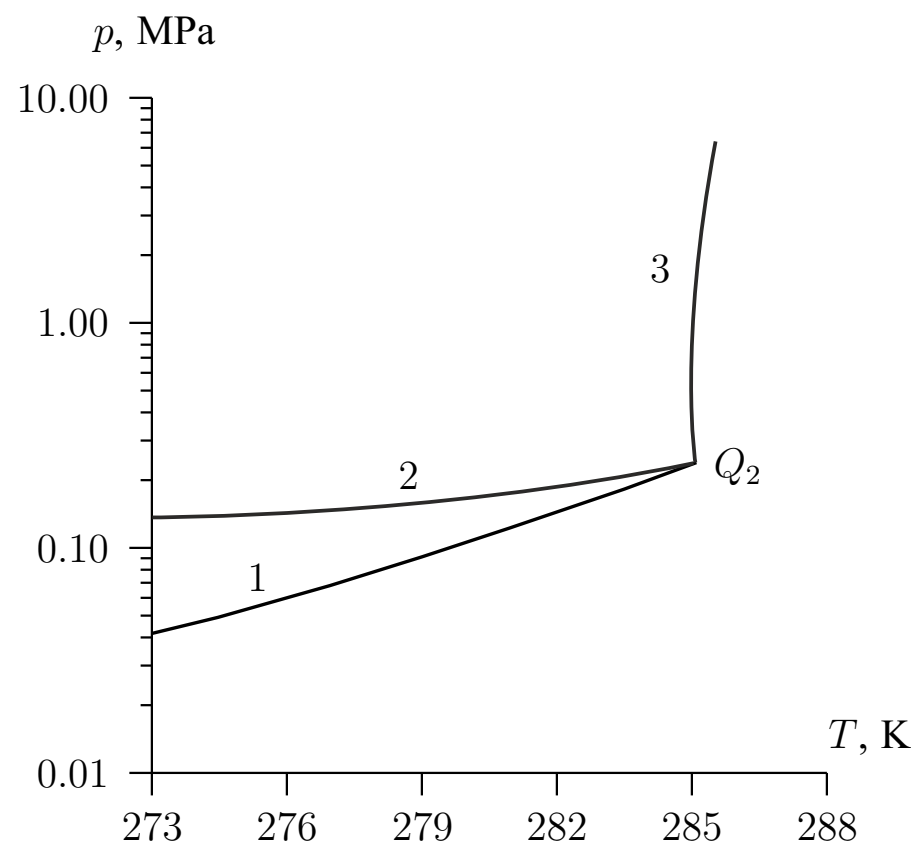

Fig. 1. Phase diagram of the system « $\mathrm{SO}_{2}-\mathrm{H}_{2} \mathrm{O} »$

The initial and border conditions have the form:

$$
\begin{gathered}
t=0: S_{w}=S_{w 0}, \quad T=T_{0}, \quad p=p_{0} \quad(x \geq 0) \\
x=0: T=T_{e}, \quad p=p_{e} \quad(t>0)
\end{gathered}
$$

In this work we consider a model with the piston displacement of methane by liquid sulfur dioxide. This is due to the fact that the viscosity of liquid sulfur dioxide is much higher than the viscosity of methane. In addition, the flows in natural strata are laminar in nature. Then we can assume that the formation of sulfur dioxide gas hydrate occurs on the front surface coinciding with the surface of methane displacement by sulfur dioxide. In this case, two typical areas are formed in the layer. In the first (nearest) zone, sulfur dioxide and its gas hydrate are present in the pores, in the second (remote) zone are water and methane. In this case, there is a mobile interfacial surface between the first and second areas, where water completely passes into the gas hydrate state (hydrate formation front). The work considers a one-dimensional model which assumes that there is no heat inflow to the formation through its roof and sole from surrounding rocks. This approximation is valid for the case of a large thickness of the reservoir.

\section{$\S 2$. Basic equations}

Let's assume the value of the initial water saturation of the porous layer does not exceed 0.2 , and then the water can be considered stationary. So the system of basic equations in the rectilinearparallel case has the form [8-10]: 


$$
\begin{gathered}
\frac{\partial}{\partial t}\left(\rho_{i} m S_{i}\right)+\frac{\partial}{\partial x}\left(\rho_{i} m S_{i} v_{i}\right)=0 \\
\rho c \frac{\partial T}{\partial t}+\rho_{i} c_{i} m S_{i} v_{i} \frac{\partial T}{\partial x}=\frac{\partial}{\partial x}\left(r \lambda \frac{\partial T}{\partial x}\right) \\
m S_{i} v_{i}=-\frac{k_{i}}{\mu_{i}} \frac{\partial p}{\partial x}, \quad k_{i}=k_{0} S_{i}^{3}, \quad(i=s, g) \\
\rho_{s}=\rho_{0 s} \exp \left(\beta_{s}\left(p-p_{0}\right)\right), \quad p=\rho_{g} R_{g} T .
\end{gathered}
$$

where $x$ is the coordinate; $t$ is the time; $m$ is the porosity; $p$ is the pressure; $T$ is the temperature; the subscripts $i=s, g$ denote, respectively, the settings of sulfur dioxide and methane; $S_{i}$ is the saturation of the pores; $\rho_{i}$ is the density; $v_{i}$ is the actual average speed; $k_{0}$ is the absolute permeability of the porous medium; $k_{i}$ is the phase permeability; $\beta_{s}$ is the coefficient of compressibility of liquid sulphur dioxide; $c_{i}$ is the specific heat capacity; $\mu_{i}$ is the dynamic viscosity; $R_{g}$ is the gas constant of methane; $\rho c$ and $\lambda$ are the effective values of the volumetric heat capacity and heat capacity for a saturated layer. The main contribution to the values of the coefficients of thermal conductivity and specific volumetric heat capacity of a saturated formation is made by the parameters of the solid skeleton. Therefore, we will consider them constant.

The relations arising from the conditions of the water mass balance, sulfur dioxide and methane, as well as the balance of heat are performed at the border between the zones:

$$
\begin{gathered}
-\frac{k_{s}}{\mu_{s}} \frac{\partial p_{1}}{\partial x}=m\left(\frac{\rho_{h}}{\rho_{s}} S_{h} G+S_{s}\right) V_{n}, \\
-\frac{k_{g}}{\mu_{g}} \frac{\partial p_{2}}{\partial x}=m S_{g} V_{n}, \\
m S_{\mathrm{h}} \rho_{\mathrm{h}}(1-G) V_{n}=m S_{w 0} \rho_{w} V_{n}, \\
\lambda \frac{\partial T_{1}}{\partial x}-\lambda \frac{\partial T_{2}}{\partial x}=m \rho_{h} L_{h} S_{h} V_{n},
\end{gathered}
$$

$G$ is the relative mass concentration of sulfur dioxide in the gas hydrate; $S_{w 0}$ is the initial water saturation of the layer; $L_{h}$ is the specific heat of $\mathrm{SO}_{2}$ gas hydrate formation from liquid sulfur dioxide and water; the subscripts $j=1,2$ denote, respectively, the parameters in the first and second zones; $V_{n}$ is the speed of the formation border of sulfur dioxide gas hydrate. Here and in what follows, the subscript $n$ denotes the parameters on the surface between the zones, and the subscripts $h$ and $w$, respectively, the parameters of gas hydrate and water.

According to the water mass balance (the third ratio of the system (2.2)) for the value of hydrate saturation in the first zone we have:

$$
S_{h}=\frac{\rho_{w} S_{w 0}}{\rho_{h}(1-G)}
$$

Using (2.1) the equations of piezoconductivity and temperature conductivity in each layer zone will be written in the form:

$$
\begin{array}{ll}
\frac{\partial p_{(1)}}{\partial t}=\chi_{(i)}^{(p)} \frac{\partial}{\partial x}\left(\frac{\partial p_{(1)}}{\partial x}\right), & \frac{\partial T_{(1)}}{\partial t}=\chi^{(T)} \frac{\partial}{\partial x}\left(\frac{\partial T_{(1)}}{\partial x}\right)+\chi^{(T)} \mathrm{X}_{(1)} \frac{\partial p_{(1)}}{\partial x} \frac{\partial T_{(1)}}{\partial x} \\
\frac{\partial p_{(2)}^{2}}{\partial t}=\chi_{(2)}^{(p)} \frac{\partial}{\partial x}\left(\frac{\partial p_{(2)}^{2}}{\partial x}\right), & \frac{\partial T_{(2)}}{\partial t}=\chi^{(T)} \frac{\partial}{\partial x}\left(\frac{\partial T_{(2)}}{\partial x}\right)+\chi^{(T)} \mathrm{X}_{(2)} \frac{\partial p_{(2)}^{2}}{\partial x} \frac{\partial T_{(2)}}{\partial x}
\end{array}
$$

where $\chi_{(1)}^{(p)}=\frac{k_{s}}{\mu_{s} m\left(1-S_{h}\right) \beta_{s}}, \chi_{(2)}^{(p)}=\frac{k_{g} p_{0}}{\mu_{g} m\left(1-S_{w 0}\right)}, \chi^{(T)}=\frac{\lambda}{\rho c}, \mathrm{X}_{(1)}=\frac{\rho_{0 s} c_{s} k_{s}}{\lambda \mu_{s} \beta_{s}}, \mathrm{X}_{(2)}=\frac{c_{g} k_{g}}{2 \lambda R_{g} T_{0} \mu_{g}}$. 
To reduce the system of nonlinear differential equations (2.1) to the system of linear differential equations (2.4), the Leibenzon linearization method was used. This method consists in replacing the variable pressure in the coefficient of the right-hand side of the piezoelectric conductivity equation with a constant pressure equal to the initial pressure in the reservoir. The compressibility factor of liquid sulfur dioxide is on the order of $10^{-9} \mathrm{~Pa}^{-1}$. Then, with pressure drops in the reservoir of about $1 \mathrm{MPa}$, we have: $\beta_{s}\left(p-p_{0}\right) \ll 1$. Then sulfur dioxide can be considered a weakly compressible liquid.

\section{§3. Self-similar solution}

We introduce a self-similar variable: $\xi=x / \sqrt{\chi^{(T)} t}$. For this variable based on (1.1), (2.3) and (2.4) we get solutions for pressure and temperature distribution in each layer zone:

$$
\begin{gathered}
p_{(1)}=p_{(\mathrm{n})}+\frac{\left(p_{\mathrm{e}}-p_{(\mathrm{n})}\right) \int_{\xi}^{\xi_{(n)}} \exp \left(-\frac{\xi^{2}}{4 \eta_{(1)}}\right) d \xi}{\int_{0}^{\xi_{(n)}} \exp \left(-\frac{\xi^{2}}{4 \eta_{(1)}}\right) d \xi}, \quad 0<\xi<\xi_{(n)}, \\
T_{(1)}=T_{(n)}+\frac{\left(T_{e}-T_{(n)}\right) \int_{\xi}^{\xi_{(n)}} \exp \left(-\frac{\xi^{2}}{4}-\mathrm{X}_{(1)} p_{(1)}\right) d \xi}{\int_{0}^{\xi_{(n)}} \exp \left(-\frac{\xi^{2}}{4}-\mathrm{X}_{(1)} p_{(1)}\right) d \xi}, \quad 0<\xi<\xi_{(n)}, \\
p_{(2)}^{2}=p_{0}^{2}+\frac{\left(p_{(\mathrm{n})}^{2}-p_{0}^{2}\right) \int_{\xi}^{\infty} \exp \left(-\frac{\xi^{2}}{4 \eta_{(2)}}\right) d \xi}{\int_{\xi_{(n)}}^{\infty} \exp \left(-\frac{\xi^{2}}{4 \eta_{(2)}}\right) d \xi}, \quad \xi_{(n)}<\xi<\infty, \\
T_{(2)}=T_{0}+\frac{\left(T_{(n)}-T_{0}\right) \int_{\xi}^{\infty} \exp \left(-\frac{\xi^{2}}{4}-\mathrm{X}_{(2)} p_{(2)}^{2}\right) d \xi}{\int_{\xi_{(n)}}^{\infty} \exp \left(-\frac{\xi^{2}}{4}-\mathrm{X}_{(2)} p_{(2)}^{2}\right) d \xi}, \quad \xi_{(n)}<\xi<\infty,
\end{gathered}
$$

where $\eta_{(j)}=\chi_{(j)}^{(p)} / \chi^{(T)},(j=1,2)$.

Based on the relations (2.2), taking into account the distributions for pressure and temperature (3.1) and (3.2), we obtain the relations to determine the self-similar coordinate of the hydrate formation surface $\xi_{(n)}$ and the pressure and temperature values on it:

$$
\begin{gathered}
\frac{\left(p_{\mathrm{e}}-p_{(\mathrm{n})}\right) \exp \left(-\frac{\xi_{(n)}^{2}}{4 \eta_{1}}\right)}{\int_{0}^{\xi_{(n)}} \exp \left(-\frac{\xi^{2}}{4 \eta_{(1)}}\right) d \xi}=A_{(1)} \xi_{(n)}, \\
\frac{\left(p_{(\mathrm{n})}^{2}-p_{0}^{2}\right) \exp \left(-\frac{\xi_{(\mathrm{n})}^{2}}{4 \eta_{2}}\right)}{\int_{\xi_{(n)}}^{\infty} \exp \left(-\frac{\xi^{2}}{4 \eta_{(2)}}\right) d \xi}=A_{(2)} p_{(n)} \xi_{(n)},
\end{gathered}
$$



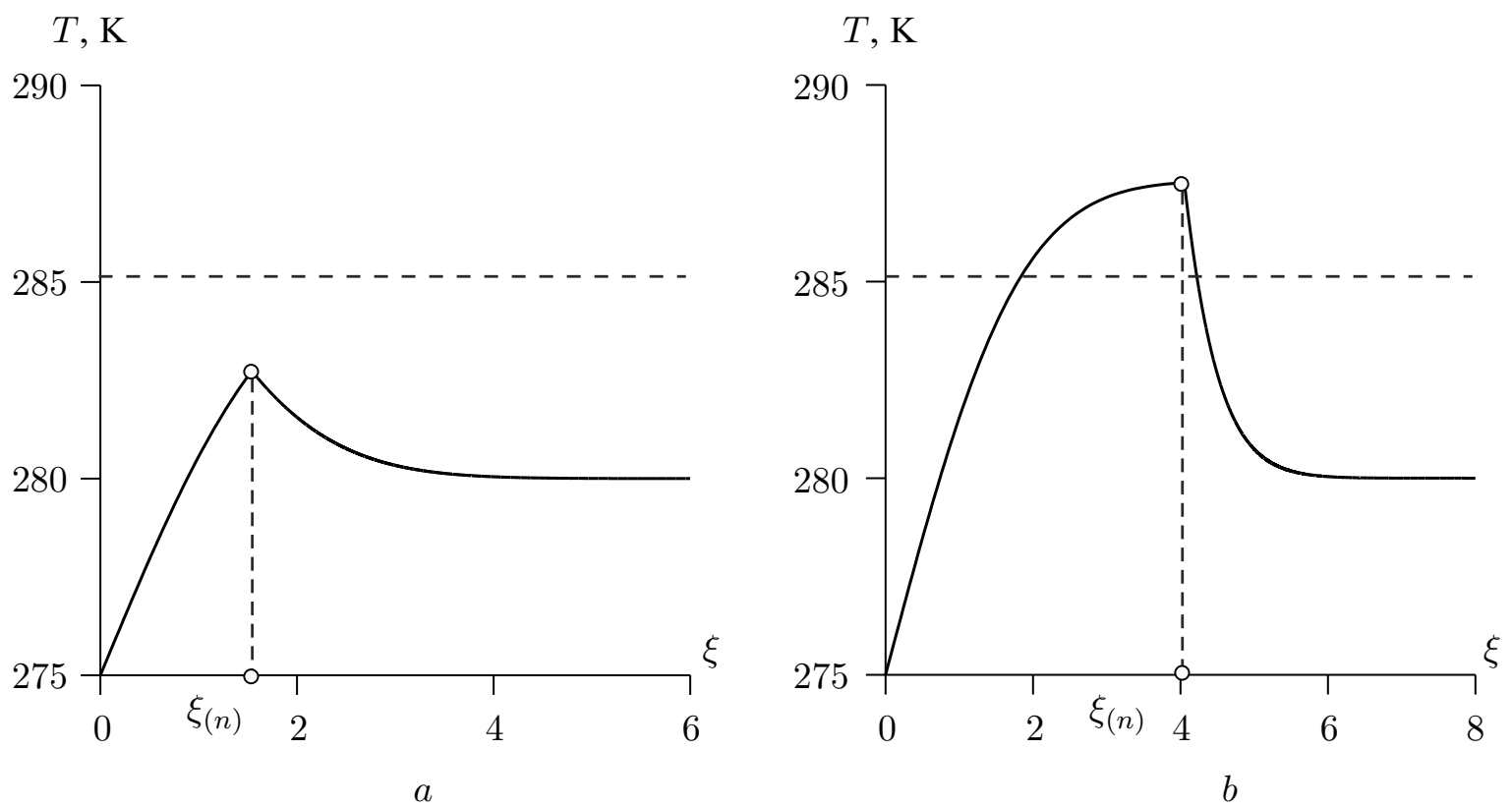

Fig. 2. Temperature distribution in the layer at the different injection pressures $p_{e}=4.1(\mathrm{a})$ and 4.4 (b) MPa. The dashed line is the temperature at the upper quadruple point

$$
\frac{\left(T_{(n)}-T_{e}\right) \exp \left(-\frac{\xi_{(n)}^{2}}{4}-X_{(1)} p_{(n)}\right)}{\int_{0}^{\xi_{(n)}} \exp \left(-\frac{\xi^{2}}{4}-\mathrm{X}_{(1)} p_{(1)}\right) d \xi}-\frac{\left(T_{0}-T_{(n)}\right) \exp \left(-\frac{\xi_{(n)}^{2}}{4}-X_{(2)} p_{(n)}^{2}\right)}{\int_{\xi_{(n)}}^{\infty} \exp \left(-\frac{\xi^{2}}{4}-\mathrm{X}_{(2)} p_{(2)}^{2}\right) d \xi}=B \xi_{(n)},
$$

where $A_{(1)}=\frac{m \mu_{\mathrm{s}} \chi^{(T)}}{2 k_{s}}\left(d \frac{\rho_{\mathrm{h}} G S_{\mathrm{h}}}{\rho_{0 \mathrm{~s}}}+1-S_{\mathrm{h}}\right), A_{(2)}=\frac{m \mu_{g} \chi^{(T)}}{k_{g}}\left(1-S_{w 0}\right), B=\frac{m \rho_{h} L_{h} S_{h}}{2 \rho c}$.

The system of equations written in this paper was solved as follows. Having achieved from equation (3.3) the pressure value at the border of gas hydrate formation $p_{(n)}$ (as a $\xi_{(n)}$ function) and substituting this value $p_{(n)}$ into equation (3.4), we obtain a transcendent equation with one unknown $\xi_{(n)}$, which was solved by the half division method. Then we determine the pressure values $p_{(n)}$ and temperature $T_{(n)}$ at the $\xi_{(n)}$ border of gas hydrate formation from equations (3.3) and (3.5).

\section{$\S 4$. The results of the calculations}

Fig. 2 shows the temperature distributions within the layer at the different pressure values of sulfur dioxide injection $p_{e}=4,1(a)$ and 4,4 $(b) \mathrm{MPa}$. The dashed line is the temperature of the upper quadruple point. For other parameters the following values are adopted: $m=$ $0,2, S_{w 0}=0,2, p_{e}=4,2 \mathrm{MPa}, p_{0}=4 \mathrm{MPa}, T_{0}=280 \mathrm{~K}, T_{e}=275 \mathrm{~K}, k_{0}=5 \cdot 10^{-15} \mathrm{~m}^{2}$, $G=0,372, \mu_{s}=3,68 \cdot 10^{-4} \mathrm{~Pa} \cdot \mathrm{s}, \mu_{g}=1 \cdot 10^{-4} \mathrm{~Pa} \cdot \mathrm{s}, \beta_{s}=1,35 \cdot 10^{-9} \mathrm{~Pa}^{-1}, \lambda=2 \mathrm{~W} /(\mathrm{m} \cdot \mathrm{K})$, $\rho c=2 \cdot 10^{6} \mathrm{~J} /(\mathrm{K} \cdot \mathrm{kg}), \rho_{h}=1390 \mathrm{~kg} / \mathrm{m}^{3}, \rho_{w}=1000 \mathrm{~kg} / \mathrm{m}^{3}, \rho_{0 s}=1434 \mathrm{~kg} / \mathrm{m}^{3}, c_{s}=1350 \mathrm{~J} /(\mathrm{K} \cdot \mathrm{kg})$, $L_{h}=2,62 \cdot 10^{5} \mathrm{~J} / \mathrm{kg}$.

According to Fig. 2, the temperature at the border of sulfur dioxide gas hydrate formation is lower than the temperature at the upper quadrupole point at low sulfur dioxide injection pressure (case $a$ ). Therefore, in this case, the model with the frontal border of sulfur dioxide gas hydrate 

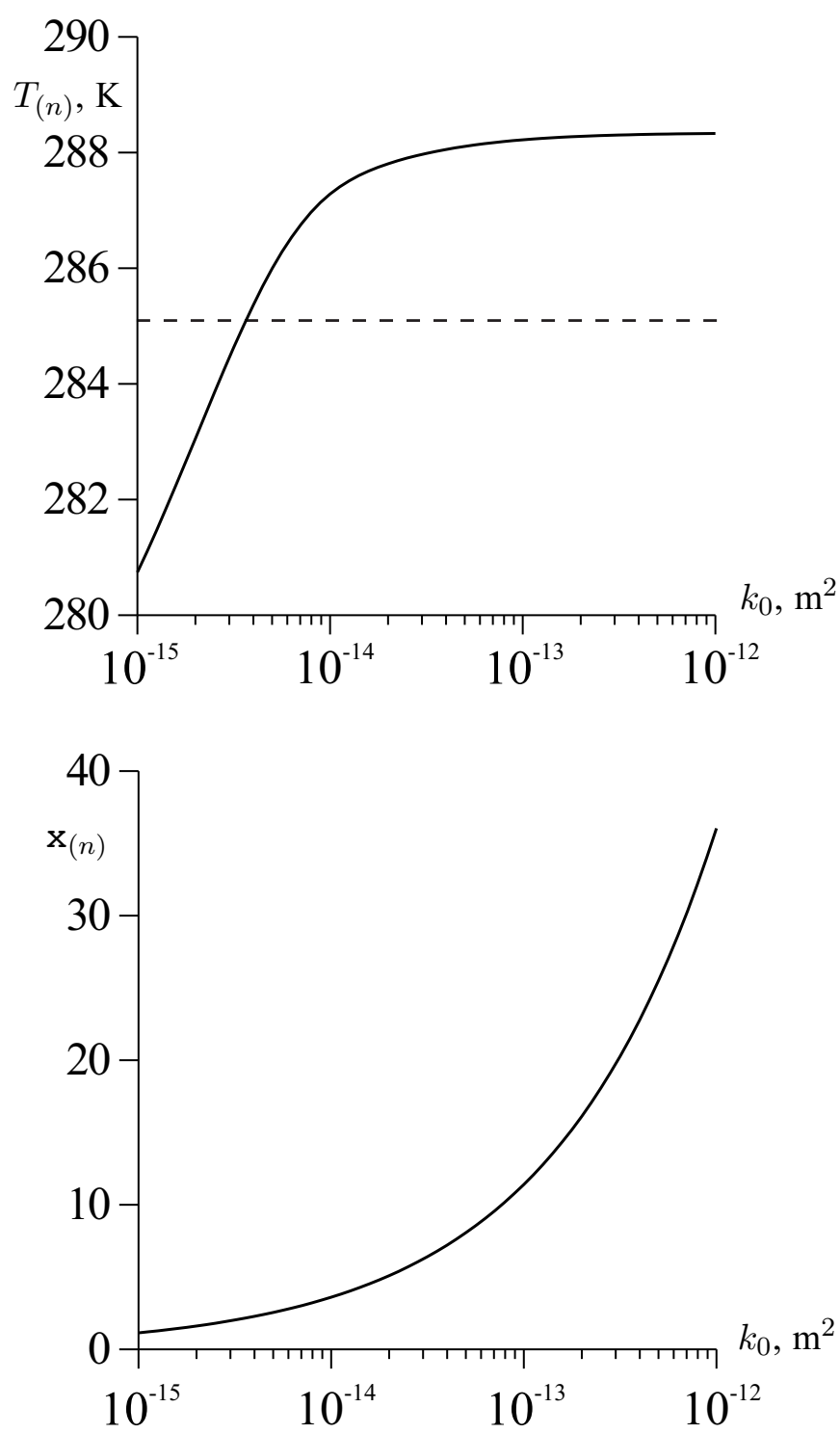

Fig. 3. The dependence of the temperature and the coordinates of the formation border of gas hydrate on the absolute permeability of the layer at $p_{e}=4.2 \mathrm{MPa}$ and $p_{0}=4 \mathrm{MPa}$. The dashed line shows the temperature of the quadrupole point

formation gives an adequate mathematical description of the process. At higher pressures of sulfur dioxide injection (case $b$ ), the temperature at the border of sulfur dioxide gas hydrate formation rises above the temperature of the upper quadrupole point. In this case, it is necessary to use a model with an extended area of phase transitions for an adequate description of the process.

Fig. 3 shows the dependence of the temperature and the coordinates of the gas hydrate formation border on the absolute permeability of the layer. According to Fig. 3, the movement rate of the hydrate formation surface increases with increasing layer permeability. This is due to the fact that the movement of the given surface is limited by the flow rate of liquid sulfur dioxide, which according to Darcy's law increases with the growth of layer permeability. Also, Fig. 3 shows that, as the layer permeability increases, during the layer permeability increasing, the temperature of the phase transition increases on the surface. This is due to the fact that hydrate formation is accompanied by the release of latent heat of the phase transitions, and the speed of the surface of phase transitions (i. e., the intensity of hydrate formation) increases with increasing permeability. In addition, as the heat part released on the phase transitions surface is discharged through the left 


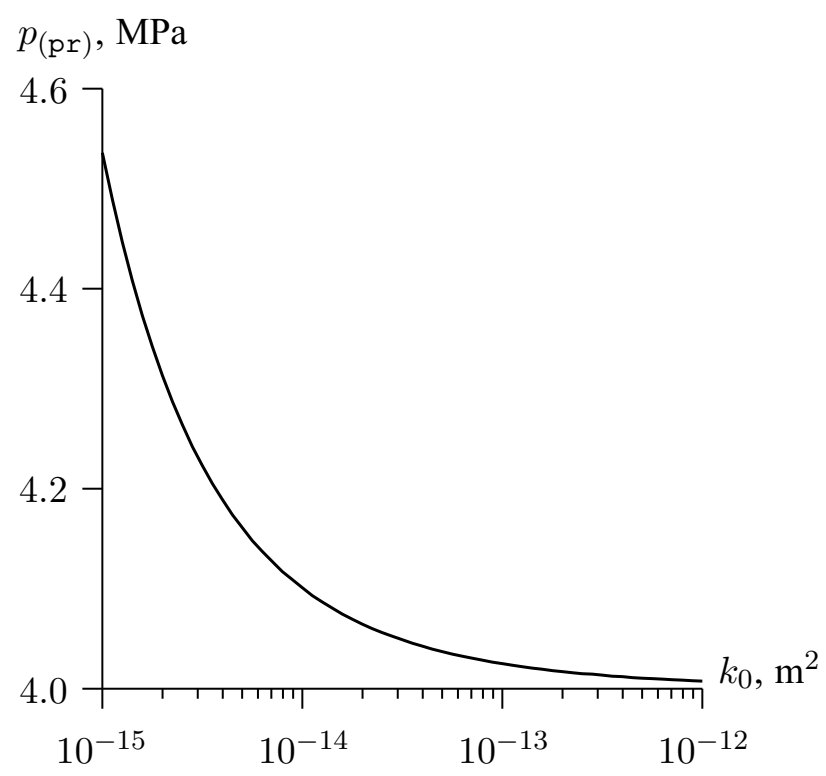

Fig. 4. The dependence of the limit pressure value on the absolute permeability

colder layer, a decrease in heat intensity removal through the left layer border takes place with increasing coordinate of the hydrate formation surface. These factors given according to Fig. 3 lead to an increase in temperature at this border with increasing layer permeability.

As a result, at sufficiently large values of layer permeability, the temperature at the hydrate formation border may exceed the equilibrium decomposition temperature of sulfur dioxide gas hydrate (dashed line), which will correspond to the appearance of an intermediate region saturated with a mixture of water, sulfur dioxide and its gas hydrate in a state of thermodynamic equilibrium. Calculations were carried out to find the limit value of the injection pressure of sulfur dioxide $p_{p r}$, above which there is an intermediate zone saturated with a mixture of water, sulfur dioxide and its gas hydrate, in a state of thermodynamic equilibrium.

Fig. 4 shows the dependence of the pressure limit on the layer absolute permeability. According to Fig. 4, as the layer absolute permeability increases, the value of the injection limit pressure increases. This is due to the fact that with a decrease in the layer absolute permeability, the temperature decreases on the formation surface of sulfur dioxide gas hydrate. Therefore, a low intensity of heat removal through the left layer border and a high intensity of the latent heat of hydrate formation is required to exceed the equilibrium decomposition temperature of the gas hydrate on this surface, it is realized at large values of the injection pressure and, accordingly, the velocity of the phase transitions border. Thus, the intermediate region saturated with a mixture of water, sulfur dioxide and its gas hydrate, locating in a state of thermodynamic equilibrium, occurs at high injection pressure values of layer permeability.

Funding. The study was funded by RFBR, project number 19-08-00967.

\section{REFERENCES}

1. Xu T., Apps J. A., Pruess K., Yamamoto H. Numerical modeling of injection and mineral trapping of $\mathrm{CO}_{2}$ with $\mathrm{H}_{2} \mathrm{~S}$ and $\mathrm{SO}_{2}$ in a sandstone formation, Chemical Geology, 2007, vol. 242, issues 3-4, pp. 319-346. https://doi.org/10.1016/j. chemgeo.2007.03.022

2. Anshits A. G., Kirik N.P., Shibistov B. V. Possibilities of $\mathrm{SO}_{2}$ storage in geological strata of permafrost terrain, Advances in the Geological Storage of Carbon Dioxide, Dordrecht: Springer, 2006, pp. 93-102. https://doi.org/10.1007/1-4020-4471-2_09 
3. Li Q., Li X., Wei N., Fang Z. Possibilities and potentials of geological co-storage $\mathrm{CO}_{2}$ and $\mathrm{SO}_{2}$ in China, Energy Procedia, 2011, vol. 4, pp. 6015-6020. https://doi.org/10.1016/j.egypro.2011.02.605

4. Sloan E. D., Koh C. A. Clathrate hydrates of natural gases, Boca Raton: CRC Press, 2007. https: //www. crcpress.com/Clathrate-Hydrates-of-Natural-Gases/Jr-Koh$\mathrm{Koh} / \mathrm{p} / \mathrm{book} / 9780849390784$

5. Wright J.F., Cote M. M., Dallimore S. R. Overview of regional opportunities for geological sequestration of $\mathrm{CO}_{2}$ as gas hydrate in Canada, Proceedings of the 6th International Conference on Gas Hydrates (ICGH 2008). Vancouver, 2008.

https://open.library.ubc.ca/cIRcle/collections/59278/items/1.0041110

6. Chuvilin E. M., Guryeva O. M. The role of hydrate formation processes in industrial $\mathrm{CO}_{2}$ sequestration in permafrost area, Proceedings of the 7th International Conference on Gas Hydrates (ICGH 2011). Edinburgh, 2011.

https://www.pet.hw.ac.uk/icgh7/papers/icgh2011Final00220.pdf

7. Chuvilin E. M., Guryeva O.M. Carbon dioxide gas hydrates accumulation in freezing and frozen sediments, Proceedings of the 6th International Conference on Gas Hydrates (ICGH 2008). Vancouver, 2008.

https://open.library.ubc.ca/cIRcle/collections/59278/items/1.0041050

8. Khasanov M.K. Regimes of hydrate formation in the process of injection of carbon dioxide into a porous medium saturated with methane and water, Journal of Engineering Physics and Thermophysics, 2018, vol. 91, issue 4, pp. 864-872. https : //doi.org/10.1007/s10891-018-1810-3

9. Gimaltdinov I. K., Kildibaeva S. R. Model of a submerged jet accounting for two limiting schemes of hydrate formation, Thermophysics and Aeromechanics, 2018, vol. 25, issue 1, pp. 75-83.

https://doi.org/10.1134/S0869864318010079

10. Khasanov M. K., Stolpovsky M. V., Gimaltdinov I. K. Mathematical model for carbon dioxide injection into porous medium saturated with methane and gas hydrate, International Journal of Heat and Mass Transfer, 2018, vol. 127, pp. 21-28.

https://doi.org/10.1016/j.ijheatmasstransfer.2018.06.028

Received 02.09.2019

Khasanov Marat Kamilovich, Candidate of Physics and Mathematics, Associate Professor, Bashkir State University, Sterlitamak Branch, pr. Lenina, 49, Sterlitamak, 453103, Russia.

E-mail: hasanovmk@mail.ru

Kil'dibaeva Svetlana Rustamovna, Candidate of Physics And Mathematics, Associate Professor, Bashkir State University, Sterlitamak Branch, pr. Lenina, 49, Sterlitamak, 453103, Russia.

E-mail: freya.13@mail.ru

Citation: M. K. Khasanov, S. R. Kil'dibaeva. Mathematical model of gas hydrate formation of sulfur dioxide by injecting liquid sulfur dioxide into a layer saturated with methane and water, Vestnik Udmurtskogo Universiteta. Matematika. Mekhanika. Komp'yuternye Nauki, 2020, vol. 30, issue 1, pp. 125-133. 


\section{М. К. Хасанов, С. Р. Кильдибаева \\ Математическая модель образования газогидрата диоксида серы при инжекции жидкой дву- окиси серы в пласт, насыщенный метаном и водой}

Ключевые слова: математическая модель, автомодельное решение, пористая среда, фильтрация, газогидраты, диоксид серы.

УДК $544.344,532.546$

DOI: $10.35634 / \mathrm{vm} 200109$

Представлены результаты теоретического исследования процесса образования газогидрата диоксида серы при инжекции жидкой двуокиси серы в пласт, насыщенный водой и метаном. Построены автомодельные решения прямолинейно-параллельной задачи. Исследованы зависимости температуры и координаты фронта образования газогидрата диоксида серы от проницаемости пласта. Установлено, что с увеличением проницаемости пласта происходит рост температуры на поверхности фазового перехода. Вследствие этого при достаточно больших значениях проницаемости пласта температура на границе гидратообразования может превысить равновесную температуру разложения газогидрата диоксида серы, что будет соответствовать возникновению промежуточной области, насыщенной смесью воды, диоксида серы и его газогидрата, находящихся в состоянии термодинамического равновесия. Установлено, что при достаточно высоких значениях давления инжекции и проницаемости образование газогидрата диоксида серы будет происходить в протяженной области.

Финансирование. Исследование выполнено при финансовой поддержке РФФИ в рамках научного проекта № 19-08-00967.

Поступила в редакцию 02.09.2019

Хасанов Марат Камилович, к. ф.-м. н., доцент, кафедра прикладной информатики и программирования, Башкирский государственный университет, Стерлитамакский филиал, 453103, Россия, г. Стерлитамак, пр. Ленина, 49.

E-mail: hasanovmk@mail.ru

Кильдибаева Светлана Рустамовна, к. ф.-м. н., доцент, кафедра прикладной информатики и программирования, Башкирский государственный университет, Стерлитамакский филиал, 453103, Россия, г. Стерлитамак, пр. Ленина, 49.

E-mail: freya.13@mail.ru

Цитирование: М. К. Хасанов, С. Р. Кильдибаева. Математическая модель образования газогидрата диоксида серы при инжекции жидкой двуокиси серы в пласт, насыщенный метаном и водой // Вестник Удмуртского университета. Математика. Механика. Компьютерные науки. 2020. Т. 30. Вып. 1. C. $125-133$. 